\title{
AT1-receptor-deficiency induced atheroprotection in diabetic mice is partially mediated via PPARY
}

\author{
Vedat Tiyerilii ${ }^{1 * \dagger}$, Ulrich M Becher ${ }^{1 \dagger}$, Adem Aksoy $^{1}$, Dieter Lütjohann², Sven Wassmann ${ }^{3}$, Georg Nickenig ${ }^{1}$ \\ and Cornelius FH Mueller ${ }^{1}$
}

\begin{abstract}
Objective: Peroxisome-proliferator-activated-receptor- $\gamma$ (PPARY) acts as a transcriptional regulator of multiple genes involved in glucose and lipid metabolism. In vitro studies showed that activated PPARY suppresses AT1R-gene expression and vice versa. However, it has not yet been determined in vivo, whether AT1R-PPARY-interactions play a relevant role in the pathogenesis of diabetic complications and specifically in accelerated atherosclerosis.

Methods and results: $\mathrm{ApoE}^{-/-}$and $\mathrm{ApoE}^{-/-} / \mathrm{AT} \mathrm{R}^{-/-}$-mice were rendered diabetic by intraperitoneal injections of streptozotocin. Diabetic and non-diabetic $\mathrm{ApoE}^{-/-}$-mice were further randomized to receive the AT1R antagonist telmisartan, the selective PPARY antagonist GW9662, telmisartan and GW9662 or vehicle for 18 weeks. Diabetic and non-diabetic ApoE ${ }^{-1-} / \mathrm{AT1R}^{-/-}$-mice were randomized to receive either GW9662 or vehicle. GW9662 treatment in diabetic $\mathrm{ApoE}^{-/-}$and diabetic $\mathrm{ApoE}^{-/-} / \mathrm{AT}^{-/-}$-mice resulted in the highest elevation of fasting blood glucose levels, whereas telmisartan treatment and AT1 deficiency in $\mathrm{ApoE}^{-/-}$-mice showed the lowest fasting blood glucose levels. Diabetic $\mathrm{ApoE}^{-/-}$-mice displayed severe impairment of endothelial function, enhanced oxidative stress and increased atherosclerotic lesion formation. ApoE $\mathrm{E}^{-/-} / \mathrm{AT} \mathrm{R}^{-/-}$and telmisartan-treated $\mathrm{ApoE}{ }^{-/-}$-mice showed a significantly better endothelial function, decreased oxidative stress and reduced atherosclerotic lesion formation. Treatment of diabetic ApoE ${ }^{-/-}$and $\mathrm{ApoE}^{-/-} / \mathrm{AT1R}^{-/-}$-mice with the selective PPARY antagonist GW9662 omitted the atheroprotective effects of AT1R deficiency or AT1 antagonism.
\end{abstract}

Conclusion: Genetic disruption or pharmacological inhibition of the AT1R attenuates atherosclerosis and improves endothelial function in diabetic $\mathrm{ApoE}^{-/-}$-mice via the PPARY pathway.

Keywords: Diabetes mellitus, Atherosclerosis, Angiotensin, Receptors

\section{Introduction}

Diabetes mellitus is a leading cause of morbidity and mortality in western countries due to cardiovascular complications [1]. It has been suggested that hyperglycaemia, insulin resistance, glycation of proteins, oxidative stress and inflammation may be related to atherogenesis in diabetes [2]. The metabolic abnormalities associated with diabetes lead to activation of the renin-angiotensinaldosterone system (RAAS) with a subsequent increase of angiotensin II (Ang II) and increased AT1-receptor (AT1R) activation [3,4]. Increased AT1R activation promotes formation of reactive oxygen species (ROS) which are in turn

\footnotetext{
* Correspondence: Vedat.Tiyerili@ukb.uni-bonn.de

${ }^{\dagger}$ Equal contributors

${ }^{1}$ Medizinische Klinik und Poliklinik II, Innere Medizin, Universitätsklinikum

Bonn, Sigmund Freud Str. 25, 53105, Bonn, Germany

Full list of author information is available at the end of the article
}

closely linked to the onset and progression of endothelial dysfunction and atherogenesis [5]. Inhibitors of the RAAS system are associated with improvement of insulin sensitivity, reduced rates of new onset of diabetes and decreased ROS formation [6-8]. So far, the causal link between these clinical observations and AT1R inhibition remains unclear. Some angiotensin receptor blockers (ARBs), such as telmisartan are partial agonists of peroxisome proliferatoractivated receptors (PPARs) [9-11]. The most abundant isoform, PPAR $\gamma$, plays an important role in the regulation of adipogenesis and insulin sensitivity [12]. Furthermore, PPAR $\gamma$ activation has been associated with anti-atherosclerotic effects including reduced formation of ROS [13]. Beneficial effects of ARBs may be partially attributed to the activation of PPAR $\gamma$ [9]. In vitro studies investigating the interaction of PPARY and the AT1R in vascular smooth muscle cells (VSMC) showed

\section{() Biomed Central}


that activated PPAR $\gamma$ suppresses AT1R gene expression and vice versa, suggesting that pharmacological blockade or genetic disruption of the AT1R leads to enhanced PPARY activity thereby mediating anti-atherosclerotic effects in the vascular compartment $[14,15]$. However, the relevance of these mechanisms has not been determined in an in vivo model of diabetes. Whether interactions of AT1R and PPAR $\gamma$ play a key role in the pathogenesis of diabetes-induced atherosclerosis remains undetermined.

In the present study we analysed the influence of AT1RPPAR $\gamma$ interactions on diabetic-induced atherosclerotic lesion formation and endothelial function in an experimental long-term diabetic mouse model. In this well characterized model, injection of the cytotoxin streptozotocin (STZ) results in a reduction in $\beta$-cells and an increase in plasma glucose to diabetic levels [4]. The validity of this model has recently been confirmed as appropriate for the study of diabetes-associated atherosclerosis by the National Institutes of Health (NIH)/Juvenile Diabetes Research Foundation (JDRF)-supported Animal Models of Diabetic Complications Consortium [16]. Our aim was to determine whether pharmacological inhibition or genetic disruption of the AT1R and the PPAR $\gamma$ pathway would interfere with the pathogenesis of diabetic vascular complications.

\section{Methods}

\section{Animals and treatment protocols}

Female, 6-week-old homozygous apolipoprotein E deficient $\left(\mathrm{ApoE}^{-/-}\right)$mice (genetic background: C57BL/6), Charles River, Sulzfeld, Germany) and AT1A receptor knockout mice $\left(\mathrm{AT}_{1} \mathrm{R}^{-/-}\right.$) with identical genetic background (kindly provided by Dr. Coffmann, University of North Carolina) were used for this study. Thirty-two $\mathrm{ApoE}^{-1-}$-mice and $12 \mathrm{ApoE}^{-/-} / \mathrm{AT}_{1} \mathrm{R}^{-/-}$-mice were rendered diabetic by 5 daily intraperitoneal injections of streptozotocin (Sigma-Aldrich, Germany) at a dose of $55 \mathrm{mg} / \mathrm{kg}$ in citrate buffer or received citrate buffer $(0.01 \mathrm{~mol} / \mathrm{l}$, $\mathrm{pH}: 4.5)$ alone (Figure 1A). All streptozotocin treated animals had blood glucose-levels $\geq 250 \mathrm{mg} / \mathrm{dl} 14$ days after the induction of diabetes. The same number of $\mathrm{ApoE}^{-/-}$-mice and $\mathrm{ApoE}^{-/-} / \mathrm{AT} \mathrm{R}^{-/-}$served as non-diabetic control animals (Figure 1A). In addition, diabetic and non-diabetic $\mathrm{ApoE}^{-/-}$-mice were randomized in 8 groups consisting of 8 animals to receive the AT1R-blocker telmisartan (SigmaAldrich, Germany) at a dose of $40 \mathrm{mg} / \mathrm{kg}$ body weight per day orally via chow or the selective PPAR $\gamma$ antagonist GW9662 (Sigma-Aldrich) i.p. at a dose of $1 \mathrm{mg} / \mathrm{kg}$ body weight every second day or telmisartan and GW9962 or vehicle for 18 weeks (Figure 1A). Diabetic and nondiabetic $\mathrm{ApoE}^{-/-} / \mathrm{AT} \mathrm{R}^{-/-}$-mice were further randomized in 4 groups consisting of 6 animals to receive either GW9662 or vehicle for 18 weeks (Figure 1A). After induction of diabetes the animals were treated for 18 weeks, had unrestricted access to water and standard mouse chow and were maintained in a room with a 12-hour light/dark cycle and a constant temperature of $22^{\circ} \mathrm{C}$. The experimental setting is depicted as flow chart in Figure 1B. After treatment of 18 weeks mice were sacrificed and read-outs were performed (Figure 1B). All animal experiments were performed in accordance with institutional guidelines and the German animal protection law.

\section{Measurements of blood pressure (BP), heart rate, blood glucose and body weight}

Systolic blood pressure and heart rate were measured by a computerized tail-cuff system (CODA 6, Kent Scientific) in conscious animals. Blood glucose levels were measured using Accu-Chek ${ }^{\circledR}$-Sensor, Roche, Mannheim, Germany). Blood samples were collected by tail vein puncture. Body weights were measured weekly and changes in body weight at baseline compared to body weight after 18 weeks of treatment were calculated.

\section{Aortic ring preparations and tension recording}

After excision of the descending aorta, the vessel was immersed in chilled, modified Tyrode buffer containing, in $\mathrm{mmol} / \mathrm{L}, \mathrm{NaCl} 118.0, \mathrm{CaCl} 22.5, \mathrm{KCl} 4.73, \mathrm{MgCl} 2$ 1.2, KH2PO4 1.2, NaHCO3 25.0, Na EDTA 0.026, D(+) glucose $5.5, \mathrm{pH}$ 7.4. Three-millimeter rings were mounted in organ baths filled with the above-described buffer $\left(37^{\circ} \mathrm{C}\right.$; continuously aerated with $95 \% \mathrm{O} 2$ and $\left.5 \% \mathrm{CO} 2\right)$ and were attached to a force transducer, and isometric tension was recorded. The vessel segments were gradually stretched over 60 minutes to a resting tension of $10 \mathrm{mN}$. The drug concentration was increased when vasoconstriction or vasorelaxation was completed. Drugs were washed out before the next substance was added.

\section{Staining of atherosclerotic lesions and morphometric analysis}

Hearts with ascending aortas were embedded in Tissue Tek OCT embedding medium and sectioned on a Leica cryostat $(9 \mu \mathrm{m})$, starting at the apex and progressing through the aortic valve area into the ascending aorta and the aortic arch and placed on poly-L-lysine (Sigma) coated slides. At least 15 consecutive sections per animal were used for analysis. For detection of atherosclerotic lesions, aortic cryosections were fixed with 3.7\% formaldehyde and stained with oil red $\mathrm{O}$ working solution. For morphometric analysis, hematoxylin staining was performed according to standard protocols. Stained samples were examined with a Zeiss Axiovert 200 microscope (Carl Zeiss Jena, Germany) and an AxioCam MRc5. Images were acquired with Zeiss AxioVision software Rel. 4.5.0 and processed with Corel Graphic Suite X4. For quantification of atherosclerotic plaque formation in the aortic root, lipid staining area and total area of serial 


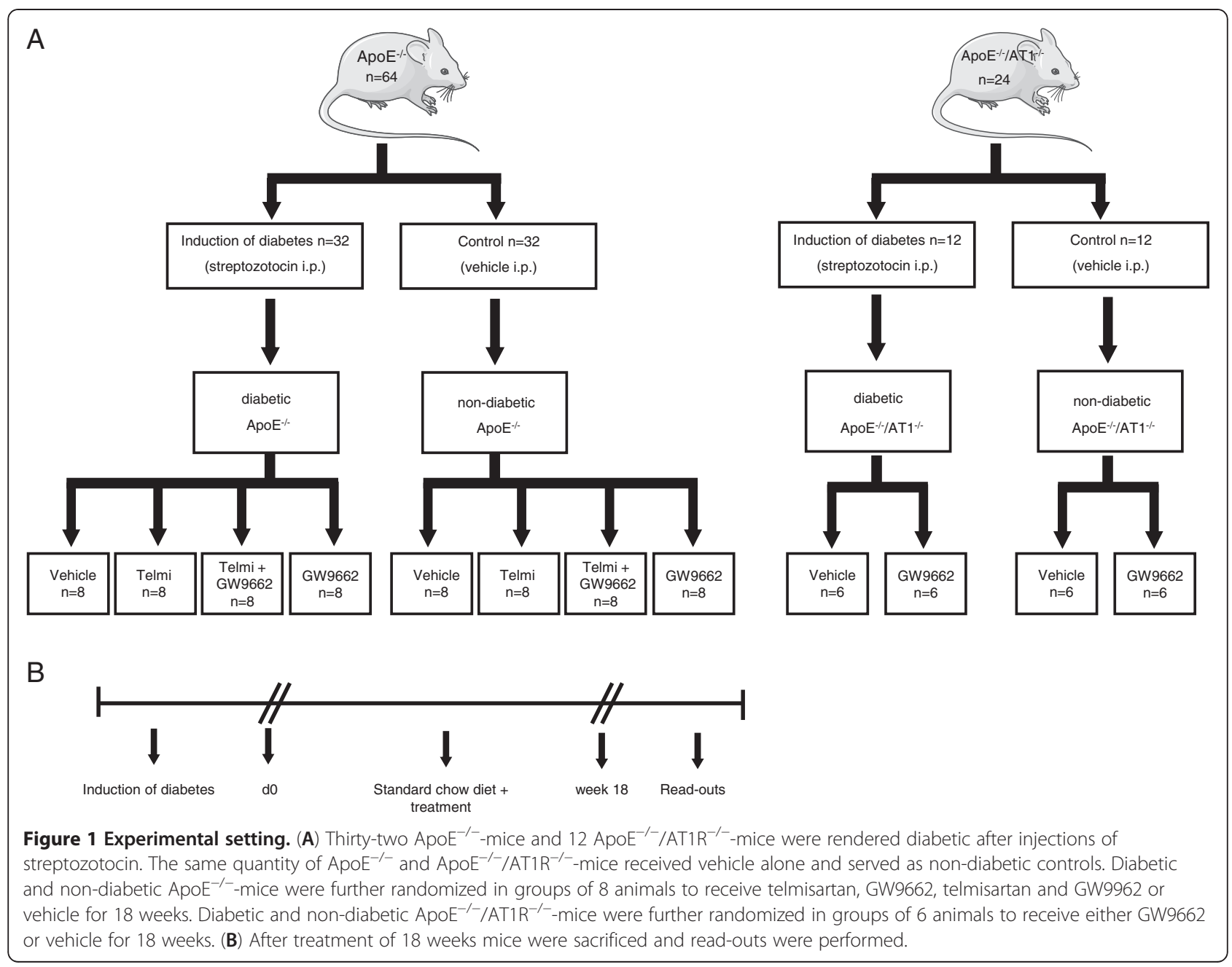

histological sections were measured. Atherosclerosis data are expressed as lipid-staining area in percent of total surface area. The investigator who performed the histological analyses was unaware of the hypothesis of this study and the treatment of the respective animal group.

\section{Measurement of vascular reactive oxygen species}

ROS release in intact aortic segments was determined by L-012 chemiluminescence, as previously described [5]. Chemiluminescence was assessed over 15 minutes in a scintillation counter (Lumat LB 9501, Berthold) at 1-minute intervals. The vessel segments were then dried, and dry weight was determined. ROS release is expressed as relative chemiluminescence per milligram of aortic tissue.

\section{Statistical analysis}

Data are presented as mean \pm SEM. Statistical analysis was performed using the ANOVA test followed by the Neuman-Keuls post hoc analysis. $P<0.05$ indicates statistical significance.

\section{Results}

Blood pressure, heart rate and metabolic parameters

Total cholesterol levels, fasting blood glucose, change in body weight, blood pressure and heart rate were measured in all groups (Table 1). Mice were treated as described in the method section and depicted in Figure $1 \mathrm{~A}$ and Figure 1B. Blood pressure $(\mathrm{mmHg})$ and heart rates $(\mathrm{bpm})$ were measured in all groups by tailcuff measurements. After 18 weeks systolic blood pressure was reduced in $\mathrm{ApoE}^{-/-} / \mathrm{AT}^{-/-}$-mice compared to $\mathrm{ApoE}^{-/-}$-mice. Heart rates were significant higher in diabetic animals. Measurements of fasting blood glucose levels showed pathological glucose levels in diabetic animals compared to non-diabetic animals. GW9662 treatment in diabetic $\mathrm{ApoE}^{-/-}$and diabetic $\mathrm{ApoE}^{-/-} /$ $\mathrm{AT}^{-1-}$-mice resulted in the highest elevation of fasting blood glucose levels. Cotreatment with telmisartan and GW9662 markedly attenuated this effect in diabetic $\mathrm{ApoE}^{-/-}$-mice. Diabetic ApoE $\mathrm{E}^{-/-}$-mice treated with telmisartan and diabetic ApoE ${ }^{-/-} / \mathrm{AT}^{-/-}$-mice showed the lowest fasting blood glucose levels compared to the 
Table 1 Blood pressure, heart rate and metabolic parameters

\begin{tabular}{|c|c|c|c|c|c|}
\hline & $\begin{array}{l}\text { Total cholesterol } \\
(\mathrm{mmol} / \mathrm{l})\end{array}$ & $\begin{array}{l}\text { Fasting blood glucose } \\
\qquad(\mathrm{mmol} / \mathrm{l})\end{array}$ & $\begin{array}{c}\text { Change in body weight } \\
\text { (\%) }\end{array}$ & $\begin{array}{l}\text { Systolic BP } \\
(\mathrm{mmHg})\end{array}$ & $\begin{array}{l}\text { Heart rate } \\
\text { (beats } / \mathrm{min} \text { ) }\end{array}$ \\
\hline \multicolumn{6}{|l|}{ Diabetic ApoE ${ }^{-I-}$} \\
\hline Vehicle $(n=8)$ & $29 \pm 3^{*, \#}$ & $23 \pm 1^{*, \#}$ & $-5,2 \pm 0.5^{*}, \#$ & $124 \pm 4^{\#}$ & $992 \pm 32^{*}$ \\
\hline Telmisartan $(n=8)$ & $31 \pm 5^{*}$ & $19 \pm 1^{*}$ & $-6,9 \pm 0.3^{*}$ & $132 \pm 9$ & $710 \pm 91$ \\
\hline Telmi + GW9662 ( $n=7)$ & $48 \pm 7^{* \neq}$ & $22 \pm 0.5^{*}$ & $-3.4 \pm 0.6^{*}$ & $124 \pm 5$ & $887 \pm 66^{*}$ \\
\hline GW9662 $(n=7)$ & $72 \pm 12^{*, \#, \neq}$ & $32 \pm 1^{*, \#, \neq}$ & $-12.4 \pm 0.6^{*, \#, \neq}$ & $123 \pm 7^{\#}$ & $1040 \pm 55^{*}, \#$ \\
\hline \multicolumn{6}{|l|}{ Diabetic ApoE/AT1 ${ }^{-/-}$} \\
\hline Vehicle $(n=6)$ & $15 \pm 5^{*}$ & $12 \pm 1^{*}$ & $12.6 \pm 0.7^{*}$ & $106 \pm 2$ & $884 \pm 70$ \\
\hline GW9662 (n=6) & $17 \pm 3^{*}$ & $19 \pm 2^{*, \#}$ & $-5.9 \pm 0.9^{*, \#}$ & $106 \pm 4$ & $772 \pm 38$ \\
\hline \multicolumn{6}{|l|}{ Non-diabetic ApoE ${ }^{-/-}$} \\
\hline Vehicle $(n=8)$ & $20 \pm 2$ & $5 \pm 0.2$ & $46 \pm 0.8$ & $123 \pm 3$ & $649 \pm 38$ \\
\hline Telmisartan $(n=8)$ & $21 \pm 3$ & $5 \pm 0.4$ & $40 \pm 0.3$ & $118 \pm 4$ & $727 \pm 21$ \\
\hline Telmi + GW9662 (n=8) & $22 \pm 2$ & $5 \pm 0.3$ & $42 \pm 0.5$ & $125 \pm 4$ & $708 \pm 42$ \\
\hline GW9662 (n=8) & $18 \pm 1$ & $4 \pm 0.4$ & $48 \pm 0.3$ & $131 \pm 3$ & $695 \pm 13$ \\
\hline \multicolumn{6}{|c|}{ Non-diabetic ApoE/AT1 ${ }^{-/-}$} \\
\hline Vehicle $(n=6)$ & $8 \pm 3$ & $5 \pm 1$ & $47 \pm 0.6$ & $102 \pm 5^{*}$ & $742 \pm 46$ \\
\hline GW9662 (n=6) & $8 \pm 3$ & $4 \pm 1$ & $50 \pm 0.5$ & $105 \pm 5^{*}$ & $679 \pm 50$ \\
\hline
\end{tabular}

To determine cardio-metabolic effects systolic BP, heart rate, fasting blood glucose levels, change in body weight and total cholesterol levels were assessed in vehicle treated diabetic and non-diabetic $\mathrm{ApoE}^{-/-}$and $\mathrm{ApoE}^{-/-} / \mathrm{AT}^{-1 \mathrm{R}^{-1-}}$-mice. ${ }^{*} \mathrm{P}<0.05$ vs. non-diabetic groups. ${ }^{\#} \mathrm{p}<0.05$ vs. corresponding diabetic $\mathrm{ApoE}^{-/-} / \mathrm{AT} \mathrm{R}^{-/-}$. ${ }^{\ddagger} \mathrm{P}<0.05$ vs. vehicle treated diabetic $\mathrm{ApoE}^{-/-}, \mathrm{n}=6-8$ per group.

other diabetic animals. At baseline (d0) body weight was identical in all groups (data not shown). After 18 weeks of standard chow diet, all groups of diabetic $\mathrm{ApoE}^{-/-}$-mice had significant more loss of body weight than the corresponding groups of diabetic $\mathrm{ApoE}^{-/-} / \mathrm{AT}_{1 \mathrm{R}^{-/-}-\text {mice. Administration of GW9662 }}$ led to a significant decrease in body weight in diabetic $\mathrm{ApoE}^{-/-}$and diabetic ApoE ${ }^{-/-} / \mathrm{AT} \mathrm{R}^{-1-}$-mice compared to vehicle treated diabetic $\mathrm{ApoE}^{-/-}$and diabetic $\mathrm{ApoE}^{-/-} / \mathrm{AT} \mathrm{R}^{-/-}$-mice. Interestingly, GW9662 treated diabetic $\mathrm{ApoE}^{-/-}$-mice lost significant more body weight then GW9662 treated diabetic ApoE ${ }^{-/-} / \mathrm{AT} \mathrm{R}^{-/-}$-mice. In contrast, all groups of non-diabetic $\mathrm{ApoE}^{-/-}$-mice and non-diabetic $\mathrm{ApoE}^{-/-} / \mathrm{AT}_{1} \mathrm{R}^{-/-}$-mice had a uniform increment in body weight after 18 weeks. Total cholesterol levels were higher in diabetic $\mathrm{ApoE}^{-/-}$-mice and diabetic $\mathrm{ApoE}^{-/-} / \mathrm{AT}^{-/-}$-mice compared to non-diabetic groups. Highest total cholesterol levels were detected in GW9662 treated diabetic $\mathrm{ApoE}^{-/-}$-mice, indicating poor glucose metabolism and increased lipolysis in GW9662 treated diabetic $\mathrm{ApoE}^{-/-}$-mice. Co-treatment with telmisartan reduced this effect significantly. GW9662 had no effect in diabetic ApoE ${ }^{-/-} / \mathrm{AT}^{-1-}$-mice. All parameters are shown in Table 1.

\section{Vascular function}

Vascular function was assessed in isolated aortic ring preparations. In contrast to diabetic $\mathrm{ApoE}^{-/-} / \mathrm{AT} \mathrm{R}^{-/-}$-mice, endothelium dependent vasodilatation was significantly impaired in diabetic $\mathrm{ApoE}^{-/-}$-mice indicating that AT1Rdeficiency attenuates endothelial dysfunction in diabetic animals. Endothelium-dependent vasodilatation was significantly impaired in GW9662 treated diabetic $\mathrm{ApoE}^{-1-}$-mice, whereas treatment with telmisartan led to a significant improvement of endothelium-dependent vasodilatation. Cotreatment with GW9662 abolished the beneficial effect of telmisartan on endothelial function (Figure 2A). In nondiabetic $\mathrm{ApoE}^{-1-}$-mice treated with vehicle or telmisartan or telmisartan and GW9662 endothelial function was not significantly affected (Figure 2B). Endothelium independent vasorelaxation induced by nitroglycerin was similar in all groups (data not shown). In addition, vasoconstriction induced by phenylephrine or KCL was similar in all groups (data not shown).

\section{Vascular oxidative stress}

Vascular release of ROS radicals was measured by L012chemiluminescence assays in intact aortic segments. Figure $3 \mathrm{~A}$ and Figure $3 \mathrm{~B}$ illustrate that vascular ROS release was significantly higher in diabetic animals than in nondiabetic animals. Diabetic ApoE ${ }^{-/-}$-mice had significantly higher ROS levels than diabetic $\mathrm{ApoE}^{-/-} / \mathrm{AT} \mathrm{R}^{-/-}$-mice. AT1R-deficiency in diabetic $\mathrm{ApoE}^{-1-}$-mice and telmisartan treatment in diabetic $\mathrm{ApoE}^{-/-}$-mice significantly decreased vascular ROS release. Co-administration of GW9662 abolished this effect, whereas treatment with GW9662 alone 

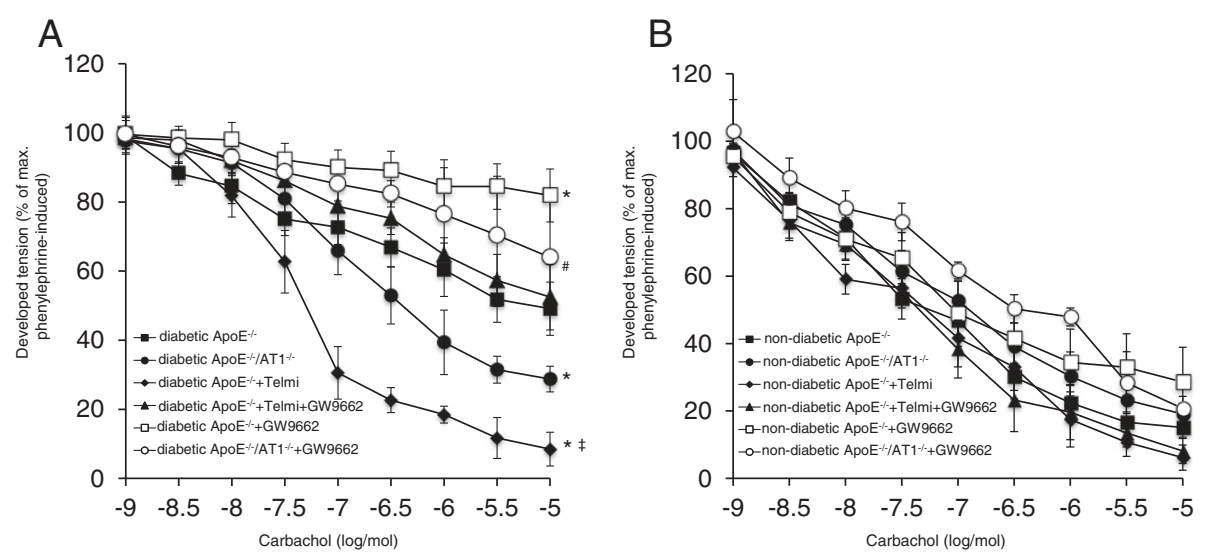

Figure 2 Vascular function. After 18 weeks aortic segments of diabetic (A) and non-diabetic (B) ApoE ${ }^{-/-}$and ApoE ${ }^{-/-} / \mathrm{ATTR}^{-/-}{ }_{-m i c e}$ were isolated and their functional performance was assessed in organ chamber experiments. Endothelium-dependent vasodilation induced by carbachol is shown. Diabetic ApoE ${ }^{-/-}$-mice displayed severe impairment of endothelial function compared to ApoE ${ }^{-/-} / \mathrm{AT1}^{\mathrm{R}^{-/-}}$-mice and telmisartan-treated $\mathrm{ApoE} \mathrm{E}^{-/-}$-mice. Treatment of diabetic $\mathrm{ApoE}^{-/-}$and $\mathrm{ApoE}^{-/-} / \mathrm{AT}^{-1 \mathrm{R}^{-/}}$-mice with $\mathrm{GW} 9662$ antagonized the protective vascular effects of AT1R deficiency or AT1 antagonism. ${ }^{*} \mathrm{P}<0.05$ vs. diabetic ApoE ${ }^{-/-}, \# P<0.05$ vs. diabetic ApoE $E^{-/-} / A_{T} 1 R^{-/-}$and ${ }^{\ddagger} P<0.05$ vs diabetic $\mathrm{ApoE}^{-/-}+$Telmisartan $+\mathrm{GW} 9662, \mathrm{n}=6-8$ per group.

induced the highest ROS release in diabetic $\mathrm{ApoE}^{-/-}$-mice (Figure 3A). In non-diabetic animals AT1R-deficiency and treatment with telmisartan reduced vascular ROS release in a comparable fashion (Figure 3B).

\section{Atherosclerotic lesion formation}

Development of atherosclerotic lesions was quantified in diabetic and non-diabetic animals using oil red $\mathrm{O}$ staining and macroscopic analysis of the aortic root after 18 weeks. Figure 4A-F and Figure 4H-M shows representative aortic root preparations of the different groups of animals. In contrast to vehicle treated nondiabetic $\mathrm{ApoE}^{-/-}$-mice (Figure 4H), vehicle treated diabetic Apo: ${ }^{-/-}$-mice (Figure 4A) displayed more atherosclerosis in the aortic root. In age-matched diabetic and non-diabetic $\mathrm{ApoE}^{-/-} / \mathrm{AT}_{1} \mathrm{R}^{-/-}$-mice, atherosclerotic lesions were significantly diminished (Figure 4B and 4I). Concurrent with the significantly improved endothelial function in telmisartan-treated diabetic $\mathrm{ApoE}^{-/-}$-mice (Figure 4C), a significant reduction in atherosclerotic lesion formation was observed compared to vehicle treated diabetic animals. Application of GW9662 in diabetic $\mathrm{ApoE}^{-/-}$-mice showed pronounced atherosclerotic lesion formation (Figure 4E). Co-administration of GW9662 and telmisartan attenuated this effect (Figure 4D). In addition, application of GW9662 significantly increased atherosclerotic lesion formation in diabetic $\mathrm{ApoE}^{-/-} / \mathrm{AT} \mathrm{R}^{-/-}$-mice (Figure 4F) compared to vehicle treated diabetic $\mathrm{ApoE}^{-/-} / \mathrm{AT} \mathrm{R}^{-1-}$-mice (Figure 4I). PPARY inhibition in GW9662 treated diabetic $\mathrm{ApoE}^{-1-}$-mice in the highest extent of atherosclerotic lesion formation (Figure 4. In non-diabetic mice (Figure 4H-N) atherosclerotic lesion formation was significantly less pronounced compared to corresponding

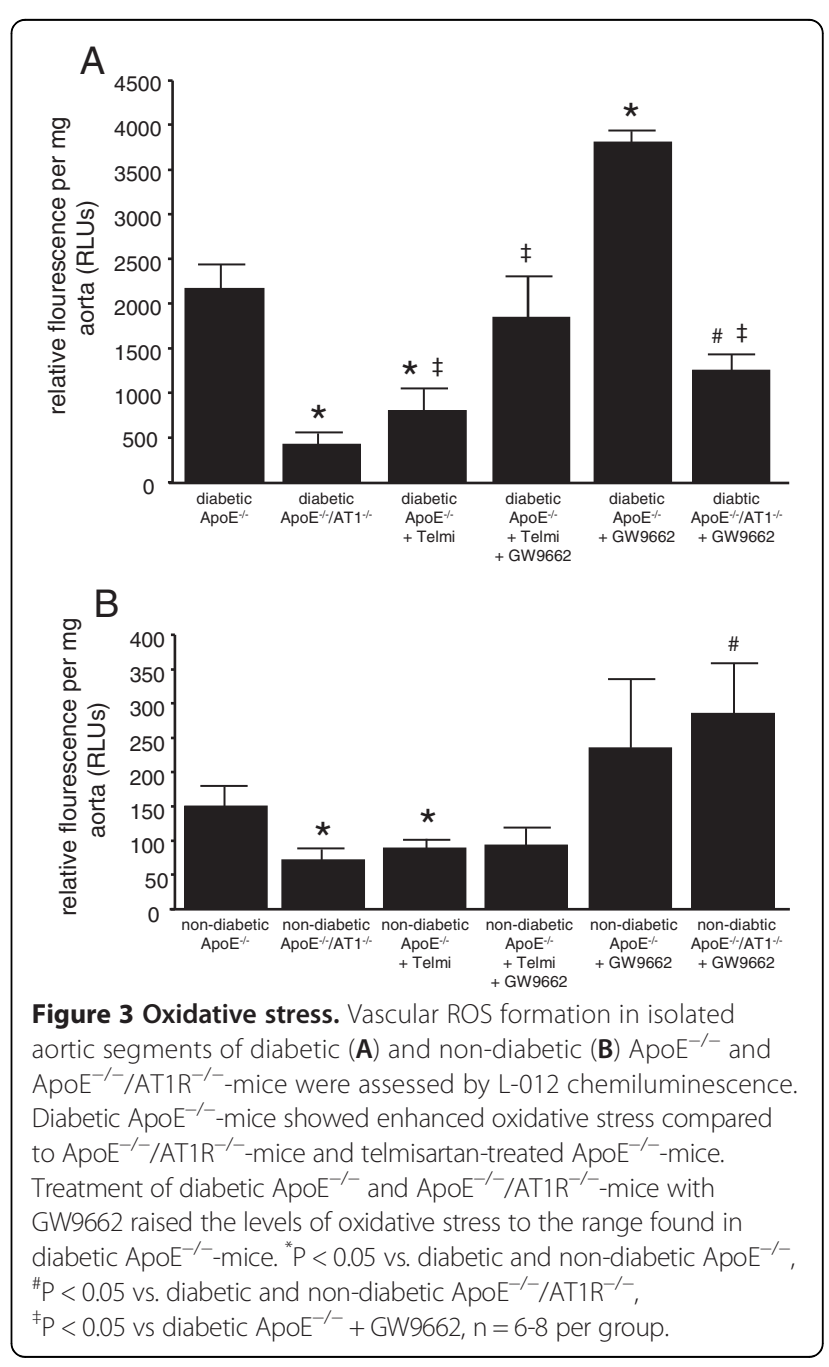




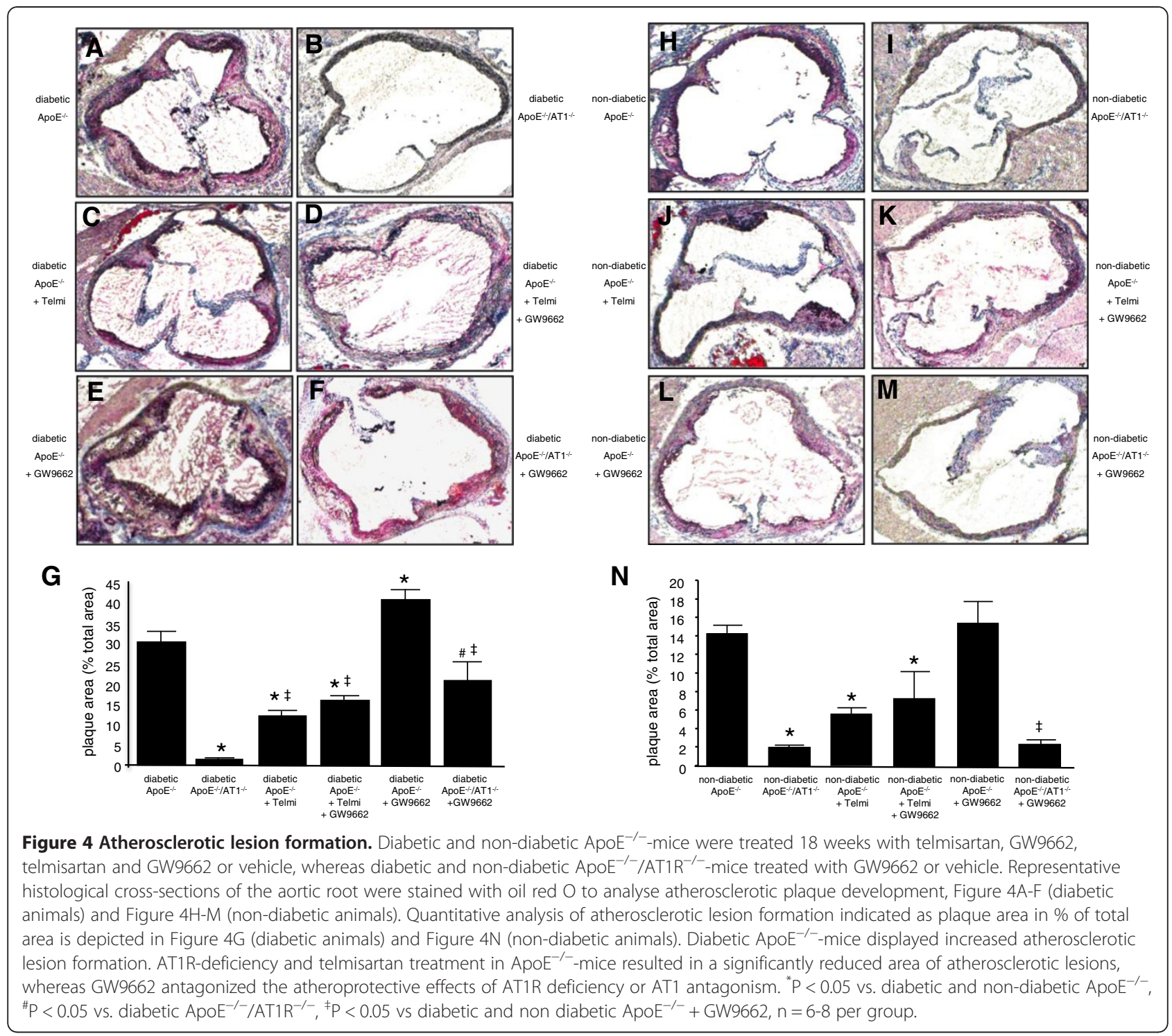

diabetic groups (Figure 4A-G). AT1R-deficiency lowered atherosclerotic plaque burden in non-diabetic

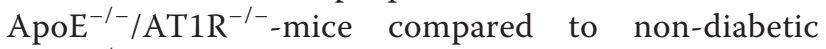
$\mathrm{ApoE}^{-1-}$-mice, indicating that AT1R-deficiency results in decreased atherogenesis not only in diabetic but also in non-diabetic conditions. Subgroup analysis in non-diabetic mice indicated that treatment with telmisar$\tan$ led to reduced atherosclerotic lesion formation in $\mathrm{ApoE}^{-/-}$-mice (Figure 4J), whereas GW9662 (Figure 4L) application showed a tendency towards more atherogenesis. Importantly, as in diabetic animals, AT1R-deficiency mediated significant atheroprotective effects in nondiabetic animals. Vehicle treated $\mathrm{ApoE}^{-/-} / \mathrm{AT}_{1} \mathrm{R}^{-1-}$-mice (Figure 4I) had significantly reduced plaque burden compared to $\mathrm{ApoE}^{-/-}$controls (Figure 4H). GW9662 treated $\mathrm{ApoE}^{-/-} / \mathrm{AT} \mathrm{R}^{-/-}$-mice (Figure $4 \mathrm{M}$ ) had significant less atherosclerotic plaques than $\mathrm{ApoE}^{-/-}$-mice treated with
GW9662 (Figure 4E). Quantitative analysis of atherosclerotic lesion formation in diabetic and non-diabetic animals is shown in Figure 4G, Figure 4N and in Additional file 1: Table S1.

\section{Discussion}

The present study demonstrates the major role of the AT1R in diabetes-induced atherogenesis. Here we show that AT1R blockade using a pharmacological approach and AT1R deficiency by gene deletion attenuates atherosclerosis and improves endothelial function in diabetic and non-diabetic $\mathrm{ApoE}^{-1-}$-mice. In addition, we show for the first time that the antiatherosclerotic effects of AT1Rinhibition are in part mediated via PPAR $\gamma$ in vivo. PPAR $\gamma$ inhibition by GW9662 treatment resulted in enhanced ROS generation and atherosclerotic lesion formation in comparison to untreated diabetic $\mathrm{ApoE}^{-/-} / \mathrm{AT} \mathrm{R}^{-/-}$-mice. 
PPAR $\gamma$ belongs to the family of peroxisome proliferatoractivated receptors, which control the expression of various genes attributed with potentially vasoprotective effects such as improved glucose metabolism, lipid homeostasis and reduction of oxidative stress $[17,18]$. Interestingly, PPAR $\gamma$ affects the expression of the AT1 receptor in vascular cells in vitro. Several authors investigated this issue in vascular smooth muscle cells and reported a downregulation of AT1 receptor expression on the transcriptional level following stimulation of PPARy [14]. Tham et al. analysed the effects of AT1 receptor activation in respect to PPARy expression in vitro and in vivo and reported a downregulation of PPAR $\gamma$ expression following stimulation with Ang II [19]. This mutual interaction is stressed by clinical observations in patients with metabolic syndrome defined by the coincidence of arterial hypertension and impaired glucose homeostasis [20]. Hypertension and the development of diabetes mellitus might interfere much closer than presently anticipated and the suggested interlocking regulation of PPARy and the AT1 receptor might be the key factor in this respect. On the other hand this interaction might explain why the use of Ang II blockers is associated with improved glucose metabolism. PPAR $\gamma$ activation by PPAR $\gamma$-agonists induces vascular protection through the improvement of lipid metabolism, anti-inflammation and anti-proliferation [10,18,21]. However, the role of the RAAS in mediating vascular protective effects of PPARy-agonists is presently not fully understood, particular not in metabolic condition of diabetes [22].

One characteristic of the PPARs is that their activation can occur through a broad spectrum of ligands even with rather low affinity [23]. This implies that particular care must be taken when assessing the PPAR $\gamma$-dependence of AT1R-signaling-pathway. Signalling pathway connected with PPAR $\gamma$ activation have been investigated in a variety of recent publications [24]. Focussing on vascular inflammation Ji and coworkers [18] found that PPAR $\gamma$ agonist treatment of vascular cells in vitro and in vivo significantly reduced proinflammatory effects of Ang II. The modulatory effects of PPAR $\gamma$ were related to diminished activation of the proinflammatory toll-like receptor 4 (TLR4). TLR4 in turn has been attributed with consecutive activation of the IP10/PKC/NF- $k$ B pathway. In contrast to Sugawara et al. PPAR $\gamma$ activation did not affect AT1 receptor expression but significantly reduced AT1 receptor dependent ERK1/2 regulation [14]. Studies published by other authors support the relevant role of the AngII/TLR4-axis in this respect [25].

Our results emphasize that AT1R-PPAR $\gamma$-interactions are in part responsible for atheroprotective effects of AT1R-deficiency. Application of the specific PPAR $\gamma$ antagonist GW9662 in diabetic $\mathrm{ApoE}^{-/-} / \mathrm{AT} \mathrm{R}^{-/-}$-mice resulted in enhanced ROS generation and atherogenesis in comparison to untreated diabetic $\mathrm{ApoE}^{-/-} / \mathrm{AT} \mathrm{R}^{-/-}$-mice. However, the here demonstrated ability of GW9662 to inhibit PPAR $\gamma$ does not rule out occurrence of a mechanism independent of PPAR $\gamma$-inhibition or counteracting AT1Raction by altering its signaling cascade olbeit in the literature, GW9662 has not been associated with pleiotropic pharmacological effects independent of PPAR $\gamma$-inhibition or associated with AT1R-interference.

Diabetes mellitus is associated with a profound risk of developing atherosclerosis and its complications such as myocardial infarction [26], stroke [27] and peripheral vascular disease [28]. In patients with diabetes, atherosclerotic lesion progression is accelerated if compared to the non-diabetic population [29]. ARBs have recently been shown to prevent the onset of diabetes in hypertensive patients and to reduce cardiovascular and renal disease progression in diabetic patients with hypertension [30-36]. Whether a specific AT1 Blocker shows higher levels of PPAR $\gamma$ agonism and whether this effect results in a clinical benefit remains an unsolved question. Our data showed that telmisartan improved oxidative stress, endothelial function and atherosclerosis while GW9662 treatment showed increased ROS levels with deleterious effects on endothelial function and atherosclerosis. These effects are much more pronounced in diabetic animals compared to non-diabetic animals. This diabetes-dependent aggravation might be partly related to the diabetes-specific over-activation of the RAAS.

In conclusion, AT1R-deficiency or pharmacological inhibition of the AT1R and activation of PPAR $\gamma$ with telmisartan in diabetic individuals have beneficial effects on oxidative stress, endothelial function and atherosclerotic plaque development especially in metabolic and RAAS abnormalities associated with diabetes indicating to a relevant interaction of PPAR $\gamma$ and the RAAS in vivo. These findings suggest a potential utility of AT1R inhibitors with partial PPAR $\gamma$ agonistic activity in the prevention and treatment of diabetic macrovascular complications.

\section{Additional file}

Additional file 1: Table S1. Absolute values of endothelial funktion, oxidative stress and atherosclerostic plaque development.

\section{Competing interests}

The authors declare that they have no competing interests.

\section{Authors' contributions}

$V T, G N$, and SW conception and design of research; $V T, A A$ and $D L$ performed experiments; VT, UMB and CFHM analyzed data; VT, UMB and CFHM interpreted results of experiments; $V T$ and $U M B$ prepared figures; $V T$, UMB and CFHM drafted manuscript; VT, UMB and CFHM edited and revised manuscript; All authors have read and approved the final version of manuscript. 


\section{Acknowledgments}

The excellent technical assistance of Isabel Paez-Maletz is greatly appreciated. Vedat Tiyerili (O-109.0033) and Ulrich M. Becher (O-109.0028) were supported by BONFOR, University of Bonn, Germany.

\section{Author details}

${ }^{1}$ Medizinische Klinik und Poliklinik II, Innere Medizin, Universitätsklinikum Bonn, Sigmund Freud Str. 25, 53105, Bonn, Germany. ${ }^{2}$ Institut für Klinische Chemie und Pharmakologie, Universitätsklinikum Bonn, Sigmund Freud Str. 25, 53105, Bonn, Germany. ${ }^{3}$ Isar Herzzentrum München, Sonnenstrasse 24-26, 80331, Munich, Germany.

Received: 2 December 2012 Accepted: 28 January 2013 Published: 1 February 2013

\section{References}

1. Muller WA: Diabetes mellitus-long time survival. J Insur Med 1998, 30:17-27.

2. Brownlee M: Biochemistry and molecular cell biology of diabetic complications. Nature 2001, 414:813-820.

3. Cooper ME: The role of the renin-angiotensin-aldosterone system in diabetes and its vascular complications. Am J Hypertens 2004, 17:16S-20S.

4. Candido R, Allen TJ, Lassila M, Cao Z, Thallas V, Cooper ME, et al: Irbesartan but not amlodipine suppresses diabetes-associated atherosclerosis. Circulation 2004, 109:1536-1542.

5. Wassmann S, Czech T, van Eickels M, Fleming I, Bohm M, Nickenig G: Inhibition of diet-induced atherosclerosis and endothelial dysfunction in apolipoprotein E/angiotensin II type $1 \mathrm{~A}$ receptor double-knockout mice. Circulation 2004, 110:3062-3067.

6. Gerstein HC, Yusuf S, Mann JFE, Hoogwerf B, Zinman B, Held C, et al: Effects of ramipril on cardiovascular and microvascular outcomes in people with diabetes mellitus: results of the HOPE study and MICRO-HOPE substudy. Heart Outcomes Prevention Evaluation Study Investigators. Lancet 2000, 355:253-259.

7. Kurtz TW, Pravenec M: Antidiabetic mechanisms of angiotensinconverting enzyme inhibitors and angiotensin II receptor antagonists: beyond the renin-angiotensin system. J Hypertens 2004, 22:2253-2261.

8. Lindholm LH, Ibsen H, Borch-Johnsen K, Olsen MH, Wachtell K, Dahlof B, et al: Risk of new-onset diabetes in the losartan intervention for endpoint reduction in hypertension study. J Hypertens 2002, 20:1879-1886.

9. Schupp M, Janke J, Clasen R, Unger T, Kintscher U: Angiotensin type 1 receptor blockers induce peroxisome proliferator-activated receptorgamma activity. Circulation 2004, 109:2054-2057.

10. Pang T, Benicky J, Wang J, Orecna M, Sanchez-Lemus E, Saavedra JM: Telmisartan ameliorates lipopolysaccharide-induced innate immune response through peroxisome proliferator-activated receptor- $\gamma$ activation in human monocytes. J Hypertens 2012, 30(1):87-96.

11. Shiota A, Shimabukuro M, Fukuda D, Soeki T, Sato H, Uematsu E, et al: Telmisartan ameliorates insulin sensitivity by activating the AMPK/SIRT1 pathway in skeletal muscle of obese $d b / d b$ mice. Cardiovasc Diabetol 2012, 11:139.

12. Guo Z, Zhang R, Li J, Xu G: Effect of telmisartan on the expression of adiponectin receptors and nicotinamide adenine dinucleotide phosphate oxidase in the heart and aorta in type 2 diabetic rats. Cardiovasc Diabetol 2012, 11:94

13. Duan SZ, Usher MG, Mortensen RM: Peroxisome proliferator-activated receptor-gamma-mediated effects in the vasculature. Circ Res 2008, 102:283-294.

14. Sugawara A, Takeuchi K, Uruno A, Ikeda Y, Arima S, Kudo M, et al: Transcriptional suppression of type 1 angiotensin II receptor gene expression by peroxisome proliferator-activated receptor-gamma in vascular smooth muscle cells. Endocrinology 2001, 142:3125-3134.

15. Takeda K, Ichiki T, Tokunou T, Funakoshi Y, lino N, Hirano K, et al: Peroxisome proliferator-activated receptor gamma activators downregulate angiotensin II type 1 receptor in vascular smooth muscle cells. Circulation 2000, 102:1834-1839.

16. Hsueh W, Abel ED, Breslow JL, Maeda N, Davis RC, Fisher EA, et al: Recipes for Creating Animal Models of Diabetic Cardiovascular Disease. Circ Res 2007, 100:1415-1427.

17. Evans RM, Barish GD, Wang YX: PPARs and the complex journey to obesity. Nat Med 2004, 10:355-361.
18. Ji Y, Lui J, Wang Z, Liu N, Gou W: PPARã agonist, rosiglitazone, regulates angiotensin II-induced vascular inflammation through the TLR4dependent signaling pathway. Lab Invest 2009, 89:887-902.

19. Tham DM, Martin-McNulty B, Wang YX, Wilson DW, Vergona R, Sullivan ME, et al: Angiotensin II is associated with activation of NF-kappaB-mediated genes and downregulation of PPARs. Physiol Genomics 2002, 11:21-30.

20. Vitale C, Mercuro G, Castiglioni C, Cornoldi A, Tulli A, Fini M, et al: Metabolic effect of telmisartan and losartan in hypertensive patients with metabolic syndrome. Cardiovasc Diabetol 2005, 15;4:6.

21. Tiyerili V, Müller CF, Fung S, Panek D, Nickenig G, Becher UM: Estrogen improves vascular function via peroxisome-proliferator-activatedreceptor- $\gamma$. J Mol Cell Cardiol 2012, 53(2):268-276.

22. Taguchi I, Inoue T, Kikuchi M, Toyoda S, Arikawa T, Abe S, Node K: Pleiotropic effects of ARB on dyslipidemia. Curr Vasc Pharmacol 2011, 9(2):129-135.

23. Desvergne $B$, Wahli W: Peroxisome proliferator-activated receptors: nuclear control of metabolism. Endocr Rev 1999, 20:649-688.

24. Westerink J, Visseren F: Pharmacological and non-pharmacological interventions to influence adipose tissue function. Cardiovasc Diabetol 2011, 10:13

25. Ji Y, Liu J, Wang Z, Lui N: Angiotensin II induces inflammatory response partly via Toll-Like receptor 4-dependent signaling pathway in vascular smooth muscle cells. Cell Physiol Biochem 2009, 23:265-276.

26. Beckman JA, Creager MA, Libby P: Diabetes and atherosclerosis: epidemiology, pathophysiology, and management. JAMA 2002, 287:2570-2581.

27. Kissela BM, Khoury J, Kleindorfer D, Woo D, Schneider A, Alwell K, et al: Epidemiology of ischemic stroke in patients with diabetes: the greater Cincinnati/Northern Kentucky Stroke Study. Diabetes Care 2005, 28:355-359.

28. Fadini GP, Miorin M, Facco M, Bonamico S, Baesso I, Grego F, et al: Circulating endothelial progenitor cells are reduced in peripheral vascular complications of type 2 diabetes mellitus. J Am Coll Cardio/ 2005, 45:1449-1457

29. Renard C, Van Obberghen E: Role of diabetes in atherosclerotic pathogenesis. What have we learned from animal models? Diabetes Metab 2006, 32:15-29.

30. Andraws R, Brown DL: Effect of inhibition of the renin-angiotensin system on development of type 2 diabetes mellitus (meta-analysis of randomized trials). Am J Cardiol 2007, 99:1006-1012.

31. Geng DF, Jin DM, Wu W, Xu Y, Wang JF: Angiotensin receptor blockers for prevention of new-onset type 2 diabetes: A meta-analysis of 59,862 patients. Int J Cardiol Int J Cardiol 2012, 155(2):236-242.

32. Julius S, Kjeldsen SE, Weber M, Brunner HR, Ekman S, Hansson L, et al: Outcomes in hypertensive patients at high cardiovascular risk treated with regimens based on valsartan or amlodipine: the VALUE randomised trial. Lancet 2004, 363(9426):2022-2031.

33. Yusuf S, Pfeffer MA, Swedberg K, Granger CB, Held P, McMurray JJV, et al: Effects of candesartan in patients with chronic heart failure and preserved left-ventricular ejection fraction: the CHARM-Preserved Trial. Lancet 2003, 9386:777-781.

34. Watanabe M, Inukai K, Sumita T, Ikebukuro K, Ito D, Kurihara S, et al: Effects of telmisartan on insulin resistance in Japanese type 2 diabetic patients. Intern Med 2010, 49(17):1843-1847.

35. Sakamoto M, Suzuki S, Hayashi T, luchi H, Isaka T, Sakamoto N, et al: Effects of candesartan in hypertensive patients with type 2 diabetes mellitus on inflammatory parameters and their relationship to pulse pressure. Cardiovasc Diabetol 2012, 11:118.

36. Nishida Y, Takahashi Y, Nakayama T, Asai S: Comparative effect of angiotensin II type I receptor blockers and calcium channel blockers on laboratory parameters in hypertensive patients with type 2 diabetes. Cardiovasc Diabetol 2012, 11:53.

doi:10.1186/1475-2840-12-30

Cite this article as: Tiyerili et al:: AT1-receptor-deficiency induced atheroprotection in diabetic mice is partially mediated via PPARY. Cardiovascular Diabetology 2013 12:30. 